\title{
WestVirginiaUniversity
}

THE RESEARCH REPOSITORY @ WVU

Graduate Theses, Dissertations, and Problem Reports

2020

\section{State Regulatory Heterogeneity and Clean Water Act Compliance}

Quinn R. Beeson

West Virginia University, qrb0002@mix.wvu.edu

Follow this and additional works at: https://researchrepository.wvu.edu/etd

Part of the Agricultural and Resource Economics Commons

\section{Recommended Citation}

Beeson, Quinn R., "State Regulatory Heterogeneity and Clean Water Act Compliance" (2020). Graduate Theses, Dissertations, and Problem Reports. 7710.

https://researchrepository.wvu.edu/etd/7710

This Thesis is protected by copyright and/or related rights. It has been brought to you by the The Research Repository @ WVU with permission from the rights-holder(s). You are free to use this Thesis in any way that is permitted by the copyright and related rights legislation that applies to your use. For other uses you must obtain permission from the rights-holder(s) directly, unless additional rights are indicated by a Creative Commons license in the record and/ or on the work itself. This Thesis has been accepted for inclusion in WVU Graduate Theses, Dissertations, and Problem Reports collection by an authorized administrator of The Research Repository @ WVU. For more information, please contact researchrepository@mail.wvu.edu. 
Graduate Theses, Dissertations, and Problem Reports

2020

State Regulatory Heterogeneity and Clean Water Act Compliance

Quinn R. Beeson

Follow this and additional works at: https://researchrepository.wvu.edu/etd

Part of the Agricultural and Resource Economics Commons 


\title{
State Regulatory Heterogeneity and Clean Water Act Compliance
}

\author{
Quinn Beeson
}

\author{
Thesis submitted \\ to the Davis College of Agriculture, Natural Resources and Design \\ at West Virginia University \\ in partial fulfillment of the requirements for the degree of \\ Master of Science in \\ Resource Economics and Management \\ Levan Elbakidze, Ph.D., Chair \\ Alan R. Collins, Ph.D. \\ Suhyun Jung, Ph.D.
}

Division of Resource Economics and Management

\section{Morgantown, West Virginia}

2020

Keywords: Clean Water Act, Safe Drinking Water Act, water quality, drinking water, wastewater, state regulations

Copyright 2020 Quinn Beeson 


\section{Abstract \\ State Regulatory Heterogeneity and Clean Water Act Compliance \\ Quinn Beeson}

This research evaluates the impact of state regulations regarding Clean Water Act (CWA) compliance on wastewater and drinking water violations in the continental United States from 2007 to 2017. Using data collected from the Environmental Protection Agency (EPA), community characteristics and state regulations are analyzed for their effects on CWA compliance. We use count data analysis techniques and annual county-level data on CWA and Safe Drinking Water Act (SDWA) violations from wastewater and drinking water facilities in the United States. The results show that total violations are higher when an additional state CWA regulation is implemented. One year after a new regulation is implemented, however, we observe a decrease in total violations relative to the number of violations prior to the introduction of additional policy or regulation. Total violations may decrease after the introduction of new regulations and policies as the facilities update their procedures, enforcement, or technology to be in compliance with new standards. Research findings confirm previous literature that higher non-white populations experience greater numbers of water violations, but also show that increased average per capita income mitigates the number of violations when the non-white population percentage is also taken into consideration. 


\section{Contents}

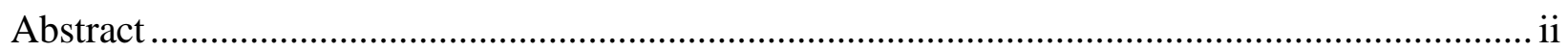

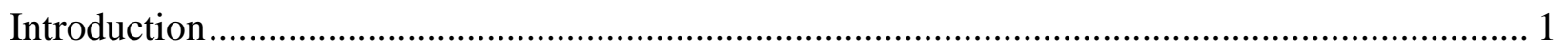

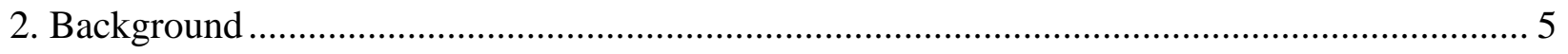

2.1 Clean Water Act (CWA) ............................................................................................ 5

2.2 Safe Drinking Water Act (SDWA) ............................................................................. 7

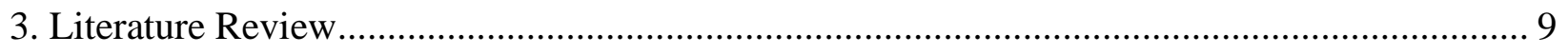

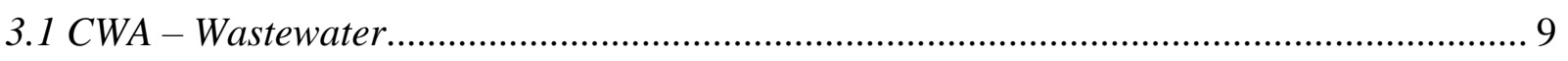

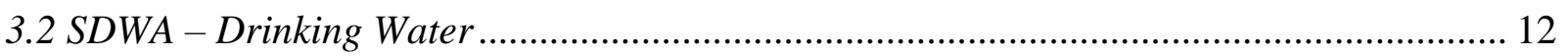

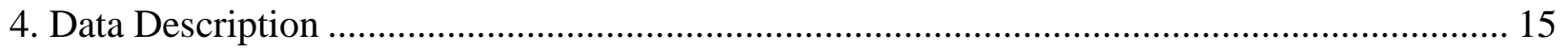

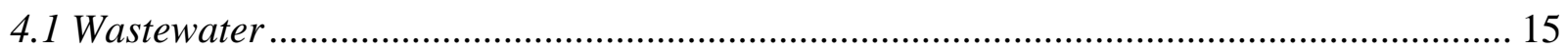

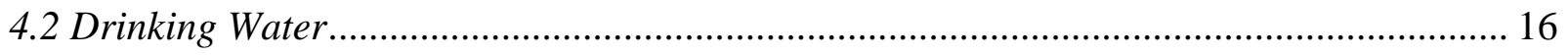

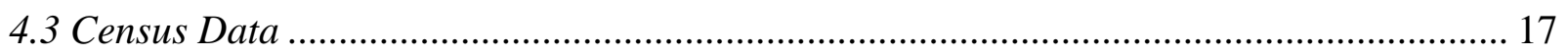

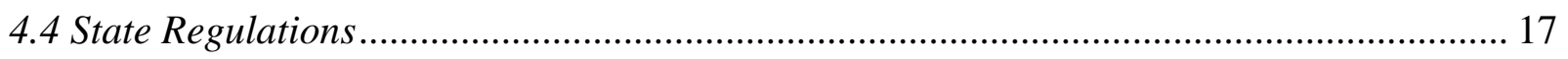

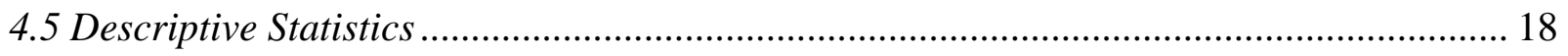

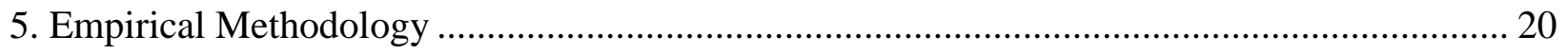

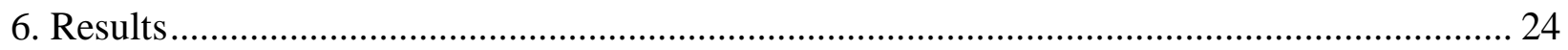

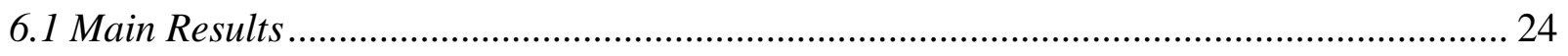

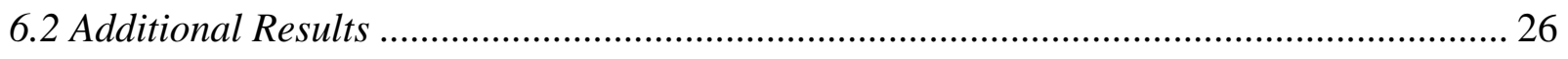

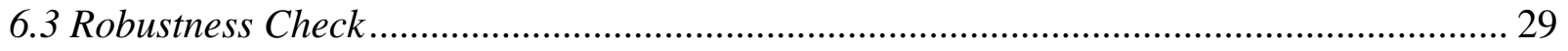

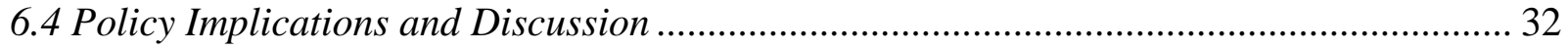

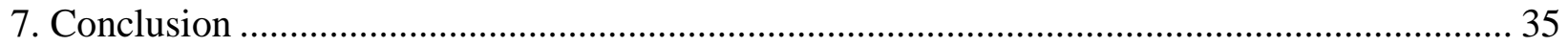

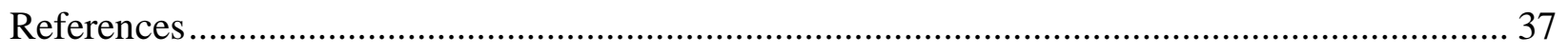

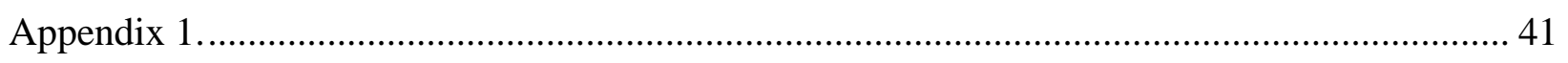




\section{Tables}

Table 1. Descriptive Statistics: County-level Annual.................................19

Table 2. Observed Frequencies of the County Annual Violations............................22

Table 3. Annual County-level Regressions........................................25

Table 4. Annual County-Level Wastewater Regressions ................................27

Table 5. Annual County-Level Drinking Water Regressions .............................29

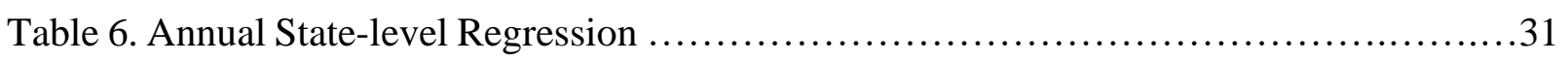

Table 7. 2017 County-level Regressions ...........................................

Figures

Figure 1. US Annual Drinking Water and Wastewater Violations..........................20 


\section{Acronyms}

ASCE American Society of Civil Engineers

CWA Clean Water Act

DMR Discharge monitoring report

EPA Environmental Protection Agency

GAO Government Accountability Office

ICIS-NPDES Integrated Compliance Information System - National Pollutant Discharge Elimination System

NB Negative binomial

NPDES National Permit Discharge Elimination System

PADEP Pennsylvania Department of Environmental Protection

PCS Permit Compliance System

SDWA Safe Drinking Water Act

SDWIS Safe Drinking Water Information System

US United States

WEF Water Environment Federation

ZINB Zero-inflated negative binomial 


\section{Introduction}

According to the American Society of Civil Engineers (ASCE, 2017), wastewater treatment plants are the most critical and basic infrastructure system for protecting the health of the nation and the environment. Clean drinking water is also needed to support daily life in developed societies. In the United States (US), there are more than 800,000 miles of public sewer lines and an additional 500,000 miles of private sewers that connect to the public sewer lines, as well as one million miles of pipes for drinking water (ASCE, 2017). Both wastewater and drinking water treatment facilities are usually overseen by a local utility or a public works department to ensure that state and federal water quality standards are met before the treated water is discharged. Approximately $76 \%$ of the US population relies on public facilities for wastewater treatment and $90 \%$ of Americans rely on the public water system for drinking water. Additionally, more than $\$ 271$ billion is needed to invest in maintaining and updating wastewater infrastructure in the United States to meet current and future needs, while an estimated \$1 trillion is needed to update drinking water infrastructure in the next 25 years (ASCE, 2017). Much of this investment is needed to update failing facilities that are struggling with water quality below the national standards, which is affecting the health of the US population (Allaire et al., 2018).

Major events in recent years such as the Flint, Michigan crisis, the Elk River chemical spill in West Virginia, and the toxic algae blooms in Toledo, Ohio have been well-publicized and brought the importance of water quality to the forefront of discussions on infrastructure needs. Concern for the health and well-being of the US population motivates the question of how often water quality standards are being violated and, perhaps more importantly, why.

The water quality standards that regulate discharge from wastewater treatment plants are under the CWA, while the provision of drinking water is regulated by the SDWA. The CWA prohibits the discharge of any regulated pollutant from a point source into navigable waters 
without a permit from the EPA. The permits set restrictions on the type and quantity of pollutants the owners of the permits can discharge. The SDWA sets regulatory standards for drinking water quality. Both the CWA and the SDWA charge states and Native American tribes with primary oversight and enforcement responsibility, with a requirement to maintain regulatory standards at least as stringent as the EPA's. In addition, the CWA regulates the overall quality of surface water in the United States, while the SDWA has regulations regarding surface water when it is treated for use as drinking water, leading to overlapping oversight between the two Acts (Tiemann, 2017).

States interpret the federal regulations differently and many have enacted their own, more stringent requirements or standards than the mandates imposed by the EPA. Therefore, comparisons of violations that occur in states with additional regulations to states where water quality standards follow only the federal regulations may be misleading if differences in regulations are not explicitly taken into account. In addition, a comparison of violation numbers across years within a state that enacted additional regulations can also be misleading without a proper account of the change in the regulatory environment. On one hand, additional state regulations could lead to more violations; stricter requirements make it more difficult for the wastewater treatment and drinking water facilities to remain in compliance. On the other hand, additional state regulations could decrease the number of violations if compliance with additional regulations requires significant updates in technology or procedures. Investment in technology and improvements in operational procedures can have a significant effect on water quality in that violations can actually decrease despite an increase in the stringency of the regulations.

We examine how state regulatory policies, as well as community characteristics, affect compliance with the CWA and the SDWA, using the most up-to-date panel data from the EPA on health-related wastewater and drinking water violations from facilities that serve a population 
of at least 500. Although drinking water quality is directly enforced by policies implemented under the SDWA, in this paper we consider the possibility that drinking water violations may be affected by state-level CWA policies because there is overlapping oversight of water bodies. Thus, we include drinking water violations that affect public health in our analysis.

A limited number of studies examine the US drinking water system's compliance with the SDWA at the national level, and no study considers the effects of the heterogeneity in state regulations on compliance with the CWA. Most of the literature that examines compliance with drinking water regulations across states relies only on the national water quality standards set by the SDWA, disregarding additional state regulations. Instead, literature that has demonstrated what affects drinking water violation occurrence has focused mainly on community characteristics and ownership of the facilities (Wallsten and Kosec, 2008; Balazs et al., 2011; Konisky and Teodoro, 2016; Allaire et al., 2018; Switzer and Teodoro, 2018). Other authors, such as Rubin (2013), focused solely on facility-level characteristics.

Some literature has discussed that states make various regulatory decisions regarding the CWA based on their unique circumstances (Travis et al., 2004), while others have pointed out that states have varying degrees of CWA enforcement (Rechtschaffen, 2004). Demonstrations of heterogeneity in state-level water quality regulations motivate the basic hypothesis. We argue that because states have primacy to implement the EPA's CWA standards, they will not do so consistently, resulting in heterogeneity in violation rates.

The most applicable literature concerning the CWA makes the argument that states have differing priorities, thus their water quality policies and enforcement will also vary. This research also examines the very localized characteristics that make states unique (Earnhart 2004;

Rechtschaffen 2004; Travis et al. 2004; Stoner 2017; Chakraborti and McConnell 2012). We contribute to the CWA and SDWA related literature by considering the number of state 
regulations implemented under the CWA, as a measure of state stringency and heterogeneity regarding water quality. There is no literature that compares wastewater quality across states, using the most up-to-date data from the EPA.

This thesis examines the variables that influence the occurrence of wastewater and drinking water violations in the continental US from 2007 to 2017. Using data collected from the EPA, we analyze whether community characteristics and CWA related state regulations affect compliance with the CWA and the SDWA. We use count data analysis techniques and annual county-level data on CWA and SDWA violations from wastewater and drinking water facilities in the United States.

We find that in the year in which additional state CWA regulations are implemented, total violations increase, i.e. the number of state CWA regulations has a positive impact on violations. One year after a new regulation is implemented, however, there is a decrease in total violations, presumedly as facilities update their procedures, enforcement, or technology to be in compliance with the new standards. Research findings also confirm previous literature that higher non-white populations experience greater numbers of water violations, but we demonstrate that increased average per capita income mitigates the number of violations when also taking the non-white population percentage into consideration.

The rest of the paper will proceed as follows: first, the CWA and SDWA backgrounds will be examined. Second, the literature review will cover papers that address both wastewater and drinking water issues. The third section will cover a data description, again addressing both wastewater and drinking water data, as well as community characteristics from census data and a description of how we define and collect separate state regulations. The fourth will be a discussion of the empirical methodology, then a discussion of the results, and finally a conclusion. 


\section{Background}

\subsection{Clean Water Act (CWA)}

In 1948, the newly passed Federal Water Pollution Control Act became the first major

US law to address water pollution. Amendments to the law in 1972 and 1977 became known as the Clean Water Act. The 1972 amendments gave the EPA authority to set wastewater standards and continue authorizing water quality standards for surface water but delegated the responsibility for issuing and enforcing the standards to individual states under the EPA's supervision (Chakraborti and McConnell, 2012). The overarching goal of the CWA is to restore and maintain the chemical, physical, and biological integrity of the nation's waters. In addition, and most applicable to this research, the CWA made it unlawful for anyone to discharge any regulated pollutant from a point source (such as a wastewater treatment plant) into navigable waters without a permit (U.S. EPA, 2017).

The CWA covers all water with a "significant nexus to navigable waters" in the United States. This includes streams, rivers, lakes, and oceans. In addition to the overall water quality of navigable waters, the CWA is responsible for standards implementing the maintenance of wetlands. This thesis will focus on the main objective of the CWA, that of wastewater standards and discharge permits.

Wastewater comes from households, businesses, and industry through public sewer lines and stormwater drains. Wastewater is any used water that comes from a household, business, school, or industry. It includes water from sanitary sewage, dishwashers, showers, car washes, laundries, and other sources. Treatment facilities remove toxins from the wastewater before discharging it back into the local water source. According to the Water Environment Federation (WEF), only $0.06 \%$ of wastewater is actual waste material (WEF, 2017). The other $99.94 \%$ is water. The waste itself may be dissolved in the water or be in particulate form. It can include 
anything from human waste, food particles, oil, dirt, pharmaceuticals, cleaning chemicals, personal care products, or any number of other chemicals and toxins.

Point sources, such as wastewater treatment facilities, are regulated by the CWA's National Pollutant Discharge Elimination System (NPDES) program. NPDES permits are issued to any facility that discharges directly into any surface water in the United States. Regulated entities include industrial and municipal facilities and include discharges from municipal wastewater overflows, stormwater, and treated sewage sludge from wastewater treatment facilities called biosolids. The EPA enforces permits by issuing administrative orders against a facility with violations, or even seeking civil or criminal penalties when necessary. Most states are responsible for monitoring facilities for NPDES program compliance, as well as enforcing permit requirements. The EPA has a responsibility to directly implement the NPDES program in four states; Idaho, New Mexico, Massachusetts, and New Hampshire (U.S. EPA, 2019a). For the purposes of this research, wastewater treatment facilities' compliance with the NPDES program is used as a proxy for CWA compliance and we include the four states where the NPDES program is implemented by the EPA.

To understand the effect of state-level regulations on violations, this research examines discharge monitoring data of public wastewater systems across the country. Facilities report pollutant discharge monitoring data in their discharge monitoring report forms (DMR), which are compared to NPDES permit requirements to determine a facility's compliance. The permit data contain the NPDES limits for water quality standards such as flow, temperature, dissolved oxygen, and specific chemicals. A violation occurs any time discharge from a treatment facility into surface waters contains a regulated pollutant amount above the permit limit.

The EPA provides a list of pollutants, originally published in 1977 for the implementation of the 1976 Toxic Pollutant List, that are regulated under the CWA, but explains 
that it is outdated and states should use the list only as a starting point when creating discharge standards and NPDES permits (U.S. EPA, 2019b). Neither Congress nor the EPA has added to the list since 1977, although a few pollutants were removed at various times by the EPA when it was concluded they did not need to be on the list (U.S. EPA, 2019b). The priority pollutant list provided by the EPA is included in Appendix 1. Many other pollutants not included on the priority pollutant list are also regulated by the CWA and individual states. Therefore, the violation data used in this research may include chemicals that are not on this list, while some chemicals on this list may not be part of the permit violations data anymore.

\subsection{Safe Drinking Water Act (SDWA)}

The Safe Drinking Water Act (SDWA) passed in 1974 and received major amendments in 1986 and 1996. The SDWA is meant to protect the US public drinking water supply and regulates both facilities and drinking water sources such as rivers, springs, reservoirs, lakes, and groundwater wells (Tiemann, 2017). The result is an overlap of regulatory standards between the SDWA and the CWA, as the CWA also regulates the same bodies of water. Most standards under the SDWA apply to the finished, treated water. However, the quality of the source water before treatment can also affect the final drinking water quality. Although drinking water quality is directly enforced by policies implemented under the SDWA, we assume in this paper that it is indirectly affected by the CWA policies because of the overlapping oversight of water bodies. Thus, by recognizing different standards for water quality across different states, this paper incorporates drinking water violations in our analysis of CWA compliance.

The EPA delegates primary enforcement responsibility of public water systems to the states but provides a list of minimum standards that must be met by public facilities (U.S. EPA, 2020a). States also experience heterogeneity in SDWA regulations (Rechtschaffen, 2004; Konisky and Teodoro, 2016; and Allaire et al., 2018). Like the CWA, the SDWA enforces 
compliance by issuing administrative orders against the drinking water facility with violations, or even seeking civil or criminal penalties when necessary.

According to the EPA, there are three different categories of public water systems, which include: a non-transient non-community water system, which may serve a population such as a school or a hospital less than year-round; a transient non-community water system, which provides water in places like gas stations and campgrounds; and a community water system, which serves the same population all year round.

Under the SDWA, drinking water facilities are required to report their violations in the Safe Drinking Water Information System (SDWIS), which is a compilation of violations of public water systems across the country. The SDWIS includes both health-related violations and monitoring and reporting problems. Violation records from the SDWIS indicate what health or reporting standard was violated, as well as the date the violation was reported by the water system authority. This thesis focuses solely on health violations, as reporting violations are mostly mistakes in paperwork rather than an indication of water quality.

The SDWIS also records what the source of the water is (groundwater or surface water), and if the water system is owned by the federal government, state government, municipality, tribe, or private organization. Additionally, the SDWIS records how the water is utilized by the system (emergency, interim, permanent, seasonal, or other). One limitation of the SDWIS is the underreporting, particularly by very small (serving less than 500 people) systems (U.S. Government Accountability Office, 2011). The US Government Accountability Office (GAO) found in 2011 that $26 \%$ of health violations were either misreported or not reported at all (U.S. Government Accountability Office, 2011). 


\section{Literature Review}

\subsection{CWA - Wastewater}

The most relevant literature regarding wastewater quality has shown that local

community characteristics affect compliance levels with the CWA and government intervention. Earnhart (2004) found that community characteristics significantly affect wastewater facility performance and regulatory interventions, such as a facility inspection from a government official, and that they affect the decision to intervene against specific facilities. Community characteristics included unemployment rate, voter turnout rate, percentage of Republican voters, high school graduation rate, population density, and per capita income. Earnhart's research focused only on major municipal treatment facilities in Kansas in 1990-1998. He measured compliance using facility inspection reports and formal enforcement actions, provided by the state of Kansas.

An article by Stoner (2017), similarly, made the case that it is difficult for small communities and poor areas to be compliant due to the inability to repay any loans or fully fund necessary projects. We therefore expect to find that counties with a low population or per capita income may have a higher occurrence of violations due to limited financial resources. Neither of these papers compared compliance across states or used NPDES data, which is the focus of this paper.

McConnell and Schwarz (1992) used wastewater data from the EPA to analyze how violations are affected by local factors, similar to the community characteristics discussed by Earnhart (2004) and Stoner (2017). They discovered that local factors such as the size of the treatment plant, flow rate of the receiving water, the area's population, regional growth, state income, and state sensitivity to environmental issues all affected a treatment plant's violations. In addition, McConnell and Schwarz found that the number of violations was also influenced by whether or not the violations would affect other states. They suggested that decreasing the 
volume of federal subsidies for wastewater treatment plants would have a negative impact on water quality.

Chakraborti and McConnell (2012) did not focus on community or local characteristics but rather found that "ambient water quality directly influenced the effluent limit chosen by the regulator" during the time period between 1990-2004 within a limited regional area of Maryland, Virginia, and Pennsylvania. Their data consisted of a sample of 100 NPDES plants from the EPA's Permit Compliance System (PCS) database. They found that permit requirements decreased, or became less stringent, when water quality improved and increased when quality worsened, even if the decreased permit requirement led to a decline in water quality in the future. They discovered that local authorities made permitting decisions based on the current water quality, which inherently changes the possibility of violations.

On another note, while some literature has shown that state policy implementation does result in differing policies between states, Travis et al. (2004) argued that not all states are capable or willing to be responsible for implementing policy based on national CWA standards. States do, however, make decisions based on their unique circumstances. They emphasized that federalism in environmental policy is the idea that "despite the EPA's understanding and intent, states do not [make decisions] on the basis of environmental needs or demand for loans, but rather, a complex interaction of environmental, financial, and cultural factors (Travis et al. 2004)." This idea motivates the basic assumption of our argument, that because states have primacy to implement the EPA's CWA standards, they will not do so identically, resulting in violations having different meanings.

Rechtschaffen (2004) also discussed why there may be differences between state implementation programs under the CWA. He highlighted that some states struggled with inadequate enforcement of wastewater permits, while other states may make a variety of 
monitoring and reporting mistakes, resulting in inaccurate and incomplete data. In the cooperative federalist system, Rechtschaffen argued that the EPA should have stepped in to remedy these problems but did not do so. A 2009 report from the GAO confirms that the federal EPA has not intervened to correct inconsistent enforcement among states (U.S. Government Accountability Office, 2009).

Going a step further, one study examined the effect of state-level corruption on compliance with the CWA (Grooms, 2015). Grooms suggested that states who transition from federal enforcement of water quality to state enforcement may experience a change in violation occurrence. She found that corrupted states, i.e. those influenced heavily by firms who wished to avoid enforcement, experienced fewer violations than non-corrupt states when they transitioned to less federal oversight. She used NPDES violation data, but examined the years 1976-2008, while we focus on the years 2007-2017, which is the data currently available from the EPA. Grooms (2015) is one of the only papers to compare state-level characteristic effects on CWA compliance. Papers mentioned previously merely make the argument that perhaps states perform differently because of varying priorities.

While a thorough discussion of different theories of federalism and their implications is beyond the scope of this paper, the basic idea is that in the United States, the national government delegates policy implementation responsibilities to the states after setting specific standards because different localities have different priorities. Helland (1998) has shown that delegation to states does, in fact, allow state and local interests to alter the federal standard. He argued that the delegation of enforcement and compliance with the CWA to states allows for different outcomes in states, particularly regarding wastewater permits and enforcement. Van't Veld and Shogren (2012) also argued that some regions or states may choose more stringent environmental standards while other regions do not. Previous literature has also made clear that 
state and national priorities with concern to environmental policy are not the same because industries vary across states (Peltzman 1976 and Pashigian 1985). Additionally, several surveys of environmental federalism have been completed, including Levinson (2003), Oates and Portney (2003), and Dijkstra and Fredriksson (2010) that provide analysis and critique beyond the scope of this thesis.

Most of the literature referenced previously concerning the CWA makes the argument that states have differing priorities, thus their water quality policies and enforcement will also vary, or examines very localized characteristics that make states unique (Earnhart, 2004; Stoner, 2017; Chakraborti and McConnell, 2012; Travis et al., 2004; van’t Veld and Shogrem 2012; Rechtschaffen, 2004; and Grooms, 2015). We contribute to the literature by considering the number of state regulations implemented under the CWA, as an indicator of state stringency regarding water quality.

\subsection{SDWA - Drinking Water}

Little peer-reviewed research has been published on national-level water system compliance with the SDWA. Rubin (2013), described the statistics for the SDWA violations using data from the SDWIS, a panel data set maintained by the EPA. Rubin (2013) focused on community water systems, which the EPA defines as a public water system that "provides water to the same population year-round (U.S. EPA, 2020b)." Rubin found that smaller water systems did not have more health violations than large water systems, although smaller water systems were more likely than large systems to have monitoring and reporting violations.

Wallsten and Kosec (2008), meanwhile, examined the effects of ownership and benchmark competition on US water system regulatory compliance using count regressions. They also use the SDWIS data, but examine all three types of public water systems, rather than just community water systems, from the years 1997 to 2003. Benchmark competition is the 
ability of consumers and regulators to compare their water service to water systems nearby. Wallsten and Kosec (2008) found that when controlling for the water source, location fixed effects, county income, urbanization, and year, overall there is a significant difference between government-owned systems and privately-owned systems. They found that for systems that serve less than 100,000 individuals, public water systems are more likely to violate health-based regulations and that private systems are more likely to violate monitoring and reporting regulations. This finding is reversed in systems that serve over 100,000 people. Importantly, they find that greater benchmark competition reduces SDWA violations.

Building on Wallsten and Kosec (2008) and Rubin (2013), Allaire et al. (2018) looked at patterns in health violations for 17,900 community water systems across the US for the years 1982 to 2015. They focused on health-based violations and emphasized findings on total coliform violations, as these violations are the best reported according to the EPA. Allaire et al. used probit regressions, with violations as a binary dependent variable, to determine the relationship between the probability of a drinking water violation occurring and characteristics of the water system and the counties they serve. They found that violations occurred more in rural areas of the country as compared to more urban areas and suggested that this may be because of a lack of funding. In addition, they used state-level fixed effects because the SDWA is primarily enforced at the state level. This thesis expands on Allaire et al. (2018) by considering states' regulatory stringency. We also examine the frequency and probability of health violations occurring.

Similar to Wallsten and Kosec (2008) and Allaire et al. (2018), Konisky and Teodoro (2016) examined whether government agencies and privately-owned drinking water utilities comply differently with the SDWA. They used SDWIS data from 2010 to 2013 for the entire US and US territories. Unlike other authors who used SDWIS data, Konisky and Teodoro examined 
both health and reporting violations. They also included only water systems that served 10,000 people or more. Similar to Allaire et al. (2018), they used state-level fixed effects but utilized negative binomial regression models rather than probit. Konisky and Teodoro (2016) focused primarily on facility ownership and found that publicly owned facilities have more health and reporting violations than privately-owned systems. In addition, the publicly owned facilities are less likely to be penalized for their violations.

Several other papers used the same SDWIS data, but for a specific state or region. Rahman et al. (2010) examined health violations of all public water systems in Arizona between 1993 and 2004. Their research is similar to Wallsten and Kosec (2008) as they examined all public water systems, not just community systems, and is similar to Allaire et al. (2018) in that they focus on only health violations. Rahman et al. (2010) used probit regressions to find that in Arizona, larger systems are more likely to have health violations than smaller systems and publicly owned facilities are more likely to have violations than privately owned facilities. In addition, systems that serve residential areas rather than schools or office buildings are more likely to have health violations.

Some literature used drinking water quality to demonstrate arguments regarding environmental justice. Switzer and Teodoro (2018) used SDWIS compliance data from 2010 to 2013 for the US to examine how race, ethnicity, and socioeconomic status affects the health violations of drinking water facilities. They looked at water systems that serve a population of at least 1,000 and were publicly owned. Switzer and Teodoro used negative binomial regression models with state-level fixed effects. They found that community racial and ethnic composition predict health violations. Likewise, poor communities with a large percentage of minority groups, are at a greater risk of health violations. Their dependent variable, health violations of 
drinking water facilities from SDWIS data, is similar to ours, as is the use of negative binomial regression models.

\section{Data Description}

\subsection{Wastewater}

The data used for this paper is from EPA's Integrated Compliance Information System National Pollutant Discharge Elimination System (ICIS-NPDES), which contains both discharge monitoring violations and permit reports of public wastewater systems across the country (U.S. EPA, 2019c). We particularly focus on the discharge monitoring data, as the permit reports do not record facilities' actual discharge. Facilities report pollutant discharge monitoring data in their discharge monitoring report forms (DMR), which are compared to NPDES permit requirements to determine a facility's compliance. The permit reports, on the other hand, contain the NPDES limits or requirements for water quality standards such as flow, temperature, dissolved oxygen, and specific chemicals. A violation occurs any time discharge contains a pollutant amount above the permit limit, found in the permit report.

In this study, the annual county-level violations are a cumulative number of annual discharge violations across all regulated pollutants reported in that county that may affect the health of a population. States may regulate different pollutants not on the EPA priority pollutant list. However, facilities are not required to monitor or report all pollutants they actually discharge, only the pollutants that a facility is required by NPDES permit to monitor.

The ICIS-NPDES database covers all 50 states, as well as 21 US territories and tribes. This paper will focus specifically on data from the continental United States, excluding Iowa, as they reported no wastewater violations for the period 2007-2017. Additionally, all facilities included in our data are publicly owned. 


\subsection{Drinking Water}

The drinking water data used by the papers highlighted in the literature review (Wallsten and Kosec 2008; Rahman 2010; Rubin 2013; Konisky and Teodoro 2016; Allaire et al. 2018; Switzer and Teodoro, 2018), and for this paper, is from the EPA's SDWIS, which is a compilation of violations of public water systems across the country (U.S. EPA, 2019d). The SDWIS includes both health-related and reporting violations. Health violations occur when treated drinking water contains more of a pollutant than permitted. Violation records from the SDWIS indicate what health or reporting standard was violated, as well as the date the violation was reported by the water system authority. We use only health violations from systems that serve a population of at least 500 .

There are three types of public water systems according to the EPA: a non-transient noncommunity water system, which may serve a population such as a school or a hospital less than year-round; a transient non-community water system, which provides water in places like gas stations and campgrounds; and a community water system, which the EPA defines as a public water system that "provides water to the same population year-round (U.S. EPA, 2020b)." This thesis focuses only on community water systems.

The SDWIS also records what the source of the water is (groundwater or surface water), and if the water system is owned by the federal government, state government, municipality, tribe, or private organization. In addition, the SDWIS records how the water is utilized by the system (emergency, interim, permanent, seasonal, or other). This study does not include drinking water systems that are owned by the federal government, as they are not under state jurisdiction. We also do not consider factors such as ownership and water utilization as our data is aggregated at the county-level rather than the facility level. 


\subsection{Census Data}

County-level characteristics were obtained from the US Census. The American

Community Survey data for the years 2007-2017 were obtained via Social Explorer. Countylevel characteristics were paired to water systems by county FIPS codes. According to Allaire et al. (2018) "Assigning census information of one county to each CWS is reasonable, given that [the majority] of systems in [the SDWIS dataset] serve only a single county" (Allaire et al. 2018). Counties that do not have a wastewater or drinking water treatment plant within their boundaries are not included in our data.

All annual data from 2007 to 2017 are official population estimates from the US Census Bureau. Per capita income is in terms of 2017 US dollars, adjusted by the consumer price index.

\subsection{State Regulations}

Annual state-level water quality regulations data are obtained from the EPA (U.S. EPA, 2019e). The data include a list of the EPA approved state water quality standards ${ }^{1}$ that the EPA has approved or are otherwise in effect for CWA purposes. The EPA updates the list for each state whenever a new standard has been approved or revised. It does not include a count of federal CWA regulations. For states that do not have additional water quality standards, the EPA proposed standards for the states to follow until they get their own approved. We did not include the proposed standards in our count. Additionally, some states have a separate regulation for one particular body of water, such as a lake or pond; we did not include these in our regulation count, as they would not affect the whole state, but rather only one locality. Future research could examine wastewater and drinking water violations at the facility level to better capture these localized regulations, as well as factors such as facility size and flow amount (McConnell and

\footnotetext{
${ }^{1}$ For clarity, we refer to these as "regulations" throughout the paper.
} 
Schwarz, 1992; Wallsten and Kosec, 2008; Rahman et al., 2010; Konisky and Teodoro, 2016; Allaire et al., 2018).

We used the separate state lists provided by the EPA to obtain the annual count of approved additional state water quality standards or regulations. We did this by creating a simple tally of the state-level regulations provided for each state. For each count, we assigned the regulation to its earliest published year and assumed that the regulation remains effective through time. We did not consider amendments. This may ignore additional effects a regulation could have on water systems, as they would potentially need to adjust to a revision or amendment.

Although this representation disregards the nature and stringency of the additional state regulations, these data enable the initial analysis of the effects of state heterogeneity in regulations on violations by considering the number of additional state regulations. The cumulative number of effective additional state regulations is used to examine the effect of statelevel heterogeneity in water quality regulations on compliance with water quality standards (U.S. EPA, 2019d). More in-depth research would include a stronger classification of all water-related regulations in a state and what the regulation or standard may be affecting, be it a pollutant standard or just a requirement of reporting by a particular date.

\subsection{Descriptive Statistics}

The data cover all continental states, excluding Iowa, over the years 2007-2017, as 2007 was the earliest NPDES data available. The average number of drinking water violations a county experiences in a year is 1.5 (see Table 1). The corresponding average number of wastewater violations is approximately 15 . The separate drinking and wastewater descriptive statistics were calculated before the two datasets were merged, meaning there are some counties not included in either the drinking or wastewater data, that are included in the other dataset. The maximum number of combined monthly county-level wastewater and drinking water violations 
is 1042 . The average number of additional state CWA regulations is 2.4 , ranging from 0 to 41 . In 2017, 38 out of 47 states had at least one additional state CWA regulation. See Figure 1 for aggregate US annual wastewater and drinking water violations.

Table 1. Descriptive Statistics: County-level Annual

\begin{tabular}{|c|c|c|c|c|c|}
\hline Variable & Description & Obs. & $\begin{array}{c}\text { Mean } \\
\text { (Std. Dev.) }\end{array}$ & Min & Max \\
\hline \multicolumn{6}{|l|}{ Violation Variables } \\
\hline $\begin{array}{l}\text { Drinking Water } \\
\text { Violations }\end{array}$ & $\begin{array}{l}\text { Count variable, the } \\
\text { number of drinking water } \\
\text { health violations within a } \\
\text { county in a given year }\end{array}$ & 31,592 & $\begin{array}{r}1.49 \\
(4.34)\end{array}$ & 0 & 103 \\
\hline Wastewater Violations & $\begin{array}{l}\text { Count variable, the } \\
\text { number of wastewater } \\
\text { violations within a county } \\
\text { in a given year }\end{array}$ & 29,747 & $\begin{array}{r}14.58 \\
(32.53)\end{array}$ & 0 & 1042 \\
\hline $\begin{array}{l}\text { Drinking and } \\
\text { Wastewater Violations }\end{array}$ & $\begin{array}{l}\text { Count variable, the } \\
\text { number of drinking and } \\
\text { wastewater violations } \\
\text { within a county in a given } \\
\text { year }\end{array}$ & 32,445 & $\begin{array}{r}14.81 \\
(31.98)\end{array}$ & 0 & 1042 \\
\hline \multicolumn{6}{|l|}{ Regulation Variables } \\
\hline $\begin{array}{l}\text { Number of State } \\
\text { CWA Regulations }\end{array}$ & $\begin{array}{l}\text { The number of state-level } \\
\text { regulations in addition to } \\
\text { CWA for each state in a } \\
\text { given year }\end{array}$ & 32,445 & $\begin{array}{r}2.49 \\
(4.06)\end{array}$ & 0 & 41 \\
\hline \multicolumn{6}{|l|}{ Census Variables } \\
\hline Population & Annual county population & 32,445 & $\begin{array}{r}102,642 \\
(324,695)\end{array}$ & 241 & $10,100,000$ \\
\hline Non-white Population & $\begin{array}{l}\text { The percent of non-white } \\
\text { population number in a } \\
\text { county in a given year }\end{array}$ & 32,445 & $\begin{array}{r}16.2 \% \\
(16.2 \%)\end{array}$ & 0 & $96.5 \%$ \\
\hline Employed Population & $\begin{array}{l}\text { The percent of the } \\
\text { population } 16 \text { years and } \\
\text { older that are employed } \\
\text { in a county in a given } \\
\text { year }\end{array}$ & 32,445 & $\begin{array}{l}43.7 \% \\
(6.2 \%)\end{array}$ & $10.2 \%$ & $74.6 \%$ \\
\hline $\begin{array}{l}\text { High School Educated } \\
\text { Population }\end{array}$ & $\begin{array}{l}\text { The percent of the } \\
\text { population } 25 \text { years and } \\
\text { older that has at least a } \\
\text { high school education in } \\
\text { a county in a given year }\end{array}$ & 32,445 & $\begin{array}{l}56.8 \% \\
(6.7 \%)\end{array}$ & $24 \%$ & $89.3 \%$ \\
\hline Per Capita Income & $\begin{array}{l}\text { Average per capita } \\
\text { income in } 2017 \text { dollars } \\
\text { per county }\end{array}$ & 32,441 & $\begin{array}{l}\$ 25,107 \\
(\$ 5,986)\end{array}$ & $\$ 8,499$ & $\$ 72,539$ \\
\hline
\end{tabular}


Both wastewater and drinking water violations aggregated at the national level can be seen in Figure 1. We see a large decrease in total wastewater violations after 2007, with a small increase peaking in 2015 and 2017. Drinking water violations initially increase from 2007 to 2008, with a gradual decrease until 2013, where violations peak in 2015, which is most likely due to a federal regulatory change in the SDWIS (Allaire et al., 2018).

Figure 1. US Annual Drinking Water and Wastewater Violations

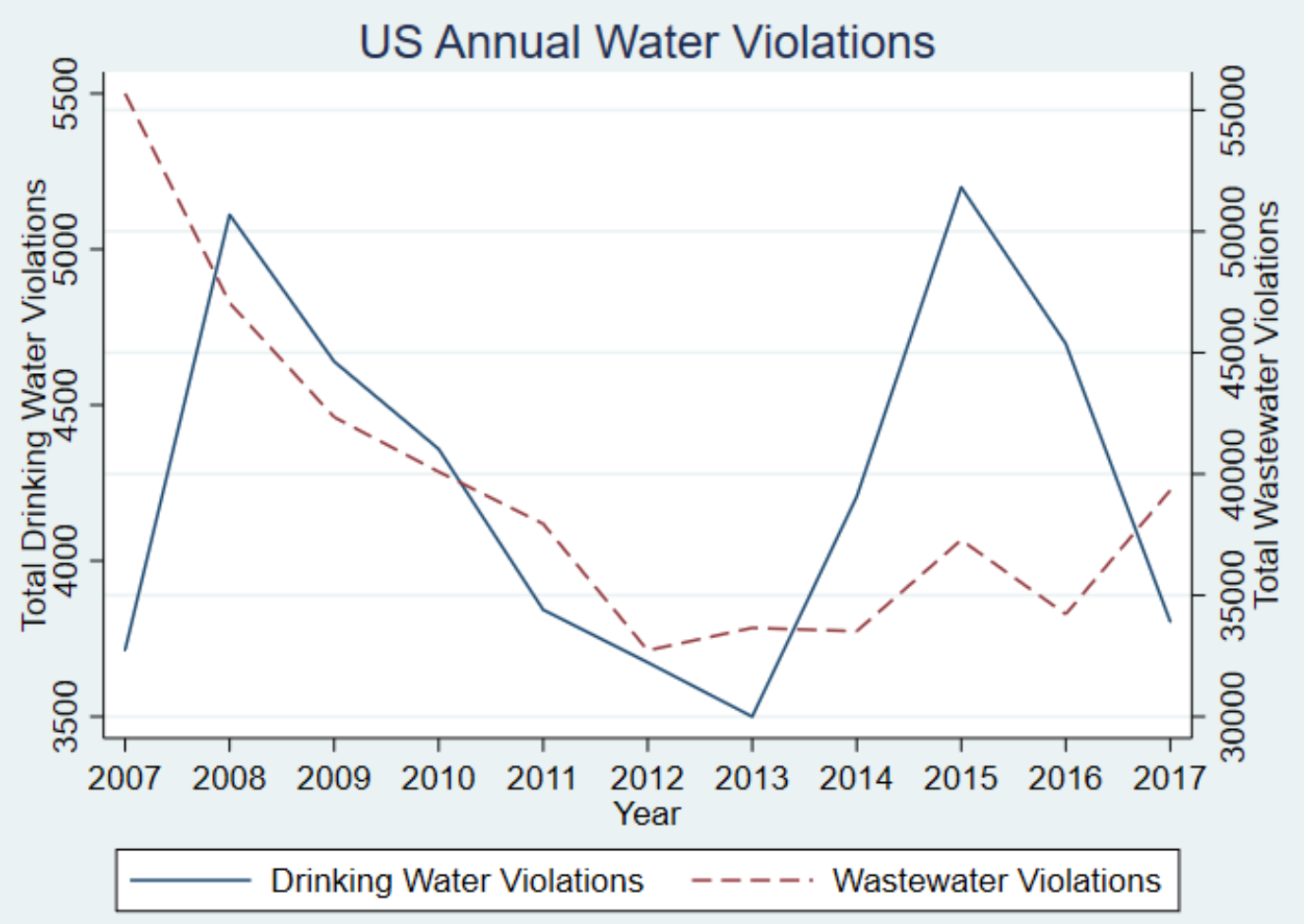

\section{Empirical Methodology}

This thesis expands on Allaire et al. (2018) by considering states' stringency with the

CWA, as well as using state-level fixed effects (Wallsten and Kosec, 2008; Allaire et al., 2018;

Konisky and Teodoro, 2016; Switzer and Teodoro, 2018). The dependent variable for our models is wastewater and drinking water violations (Grooms, 2015; Rubin, 2013; Wallsten and Kosec, 
2008; Allaire et al. 2018; Konisky and Teodoro, 2016; Rahman et al., 2010; Switzer and Teodoro, 2018). We examine both the frequency of violations occurring, as well as the probability with the use of logit models (Rahman et al., 2010; Allaire et al., 2018; Switzer and Teodoro, 2018).

In addition to including the number of implemented state regulations, independent variables included in the regressions are county-level population characteristics such as population, non-white population, employed population, high school educated population, and average per capita income (Earnhart, 2004; McConnell and Schwarz, 1992; Wallsten and Kosec, 2008; Allaire et al., 2018; Switzer and Teodoro, 2018).

As our data are count data, a first step would be to use a Poisson regression model, where a major assumption is that the mean and variance are equal (Cameron 1998). A likelihood ratio test of our count data, however, with a test statistic of 21,000 and a p-value of 0.000 , rejects the hypothesis of mean and variance equality. The large test statistic suggests that the dependent variable is over-dispersed and is not sufficiently described by the Poisson model. To address this overdispersion due to heterogeneity, we rely on Negative Binomial (NB) regressions (Long and Freese 2014). The NB regressions in this study reflect the panel nature of the data and have manual year- and state-level fixed effects. Year fixed effects control for changes in federal regulations or compliance over time. State-level fixed effects control time invariant state characteristics. Only 47 states are included in the models, as Alaska and Hawaii are not part of the continental United States and Iowa was dropped because they reported no wastewater regulations.

Another explanation for overdispersion is a significant share of zero dependent variable observations that are generated by a stochastic process which differ from the NB distribution. This is of concern for our data, as $26 \%$ of the total violation observations have zero values, while 
wastewater violations and drinking water violations separately are $34 \%$ and $68 \%$ zero values, respectively (see Table 2).

Table 2. Observed Frequencies of the County Annual Violations Total Violations Wastewater Violations Drinking Water Violations

\begin{tabular}{|c|c|c|c|c|c|c|c|c|}
\hline $\begin{array}{l}\text { Observed } \\
\text { Counts }\end{array}$ & Freq. & Percent & $\begin{array}{l}\text { Observed } \\
\text { Counts }\end{array}$ & Freq. & Percent & $\begin{array}{l}\text { Observed } \\
\text { Counts }\end{array}$ & Freq. & Percent \\
\hline 0 & 8403 & 25.9 & 0 & 11012 & 33.94 & 0 & 22091 & 68.09 \\
\hline 1 & 2568 & 7.91 & 1 & 2202 & 6.79 & 1 & 3719 & 11.46 \\
\hline 2 & 2232 & 6.88 & 2 & 2212 & 6.82 & 2 & 1740 & 5.36 \\
\hline 3 & 1448 & 4.46 & 3 & 1219 & 3.76 & 3 & 1011 & 3.12 \\
\hline 4 & 1548 & 4.77 & 4 & 1402 & 4.32 & 4 & 977 & 3.01 \\
\hline $5+$ & 16246 & 50.07 & $5+$ & 14398 & 44.38 & $5+$ & 2907 & 8.96 \\
\hline
\end{tabular}

The Vuong test confirms that a significant share of zero dependent variable observations is generated by a stochastic process that differs from the NB distribution (Vuong, 1989 and Greene, 1994). We use the bias corrected Vuong test as the ordinary Vuong test can produce biased results (Desmarais and Harden, 2013 and Wilson, 2015).

Therefore, we use a Zero Inflated Negative Binomial (ZINB) specification (Mullahy, 1986; Heilbron, 1994; Welsh et al., 1996; Yip and Yau, 2005). Zero-inflated count data models are designed to distinguish between zeros generated from different processes. When analyzing count data, there may be a significant number of zeros. However, zeros can occur for different reasons or processes. In this data, a water system may have a zero for a given year because they are compliant with both federal and state water regulations and do not have any violations. Another water system may have zero violations for a given year due to a lack of proper reporting. This first water system was certain to have no violations because of the strictness of the additional state regulations, as well as its monitoring capabilities. The second water system could have had a violation if underreporting had occurred but did not. 
Zero-inflated negative binomial models cannot be estimated using a panel data structure; thus, a comparison of panel NB and pooled ZINB regressions will have to suffice (Elbakidze and Jin, 2015). We examine total combined violations as well as disaggregated drinking water and wastewater violations for the years 2007-2017. The ZINB regression models have year- and state-level fixed effects.

As a robustness check, we include both a conditional logit and a logit regression model. A conditional logit model is similar to a fixed effects logit model for panel data but does not have biased results (Chamberlain 1980; Greene 2002). It fits maximum likelihood models with a dichotomous dependent variable and differs from a regular logit model in that the data are grouped and the likelihood is calculated relative to each group. In our case, the group is counties. We also include a logit regression model with state and year fixed effects, consistent with Allaire et al. (2018). We include both conditional logit and logit regression models to check the robustness and consistency of the results. Additional robustness check analysis includes a NB regression at the state-level with year fixed effects and regression models run for just the year 2017 with state-level fixed effects.

Additional regression models using wastewater and drinking water violations as separate dependent variables with both year and state-level fixed effects are also examined. These models include a negative binomial model, a zero-inflated negative binomial model, a conditional logit model, and a logit model with state fixed effects, similar to the main regression models in Table 3. Wastewater regressions can be found in Table 4 and drinking water regressions in Table 5, before the robustness check analysis. 


\section{Results}

\subsection{Main Results}

As shown in Table 3, results from both the panel NB regression model and the ZINB model are similar. Column 1 shows coefficients - with the associated standard errors below from the panel NB model. Column 2 presents the coefficients and standard errors of the ZINB model. Columns 3 and 4 show the results for two of the models we use for a robustness check, a conditional logit and a logit state fixed effects model. Columns 3 and 4 will be discussed in the robustness analysis.

The main regression models (columns 1 and 2) show that state regulations have a positive relationship with the number of county-level wastewater and drinking water violations in the contemporaneous year. However, we observe that as these regulations take effect over time - as demonstrated by the one-year lagged regulation variable - the regulatory effect becomes negative and significant. The coefficients of state regulations demonstrate that the year a policy or regulation is implemented, total violations become higher. One year after a new regulation is implemented, however, counties experience a decrease in total violations as they update their procedures, enforcement, or technology to be in compliance with new standards.

In addition, several county characteristic variables are consistent across both the NB and the ZINB models and reflect what is found in the literature. We see that as both the total population and the percentage of non-white population increase, the number of violations also increases (Wallsten and Kosec, 2008). Additionally, as the percentage of the employed population increases, violations decrease. These results are consistent with those found in the literature such as Earnhart (2004) and Allaire et al. (2018). While the per capita income coefficient is positive in both the NB and the ZINB models, it is insignificant. However, the interaction term between non-white population percentage and per capita income shows that as 
the effect of per capita income increases, the effect of the non-white population decreases

(Switzer and Teodoro, 2018).

Table 3. Annual County-level Regressions

\begin{tabular}{|c|c|c|c|c|}
\hline $\begin{array}{l}\text { Drinking and Wastewater } \\
\text { Violations }\end{array}$ & $\begin{array}{c}\text { (1) } \\
\text { Negative } \\
\text { Binomial, FE }\end{array}$ & $\begin{array}{c}(2) \\
\text { Zero-Inflated } \\
\text { Negative Binomial }\end{array}$ & $\begin{array}{c}(3) \\
\text { Conditional } \\
\text { Logit }\end{array}$ & $\begin{array}{l}(4) \\
\text { Logit }\end{array}$ \\
\hline Population, log & $\begin{array}{l}0.232 * * * \\
(0.0151)\end{array}$ & $\begin{array}{l}0.472 * * * \\
(0.0101)\end{array}$ & $\begin{array}{c}1.214 \\
(1.077)\end{array}$ & $\begin{array}{l}0.644 * * * \\
(0.0270)\end{array}$ \\
\hline Non-white percent of pop. & $\begin{array}{l}24.57 * * * \\
(3.302)\end{array}$ & $\begin{array}{l}20.66 * * * \\
(2.299)\end{array}$ & $\begin{array}{l}-3.375 \\
(34.35)\end{array}$ & $\begin{array}{c}38.17 * * * \\
(7.727)\end{array}$ \\
\hline Employed percent of pop. & $\begin{array}{c}-0.885 * * * \\
(0.334)\end{array}$ & $\begin{array}{l}-0.249 \\
(0.274)\end{array}$ & $\begin{array}{c}1.852 \\
(2.880)\end{array}$ & $\begin{array}{l}1.247^{*} \\
(0.666)\end{array}$ \\
\hline $\begin{array}{l}\text { High school educated } \\
\text { percent of pop. }\end{array}$ & $\begin{array}{c}0.109 \\
(0.303)\end{array}$ & $\begin{array}{c}0.546 * * \\
(0.213)\end{array}$ & $\begin{array}{c}2.190 \\
(2.969)\end{array}$ & $\begin{array}{c}2.303 * * * \\
(0.523)\end{array}$ \\
\hline Per capita income avg. & $\begin{array}{c}0.200 \\
(0.131)\end{array}$ & $\begin{array}{c}0.0901 \\
(0.0988)\end{array}$ & $\begin{array}{c}0.284 \\
(1.131)\end{array}$ & $\begin{array}{l}-0.0947 \\
(0.259)\end{array}$ \\
\hline $\begin{array}{l}\text { Interaction of Non-white } \\
\% \text { and Per capita income }\end{array}$ & $\begin{array}{l}-2.523 * * * \\
(0.331)\end{array}$ & $\begin{array}{l}-2.080 * * * \\
(0.231)\end{array}$ & $\begin{array}{l}-0.0327 \\
(3.446)\end{array}$ & $\begin{array}{c}-3.841 * * * \\
(0.773)\end{array}$ \\
\hline $\begin{array}{l}\text { Number of state } \\
\text { regulations }\end{array}$ & $\begin{array}{c}0.0511 * * * \\
(0.0103)\end{array}$ & $\begin{array}{l}-0.00803 \\
(0.0164)\end{array}$ & $\begin{array}{l}0.201 * * * \\
(0.0566)\end{array}$ & $\begin{array}{l}0.162 * * * \\
(0.0482)\end{array}$ \\
\hline Regulations lagged $1 \mathrm{yr}$ & $\begin{array}{c}-0.0457 * * * \\
(0.0101)\end{array}$ & $\begin{array}{c}-0.0558 * * * \\
(0.0178)\end{array}$ & $\begin{array}{c}-0.306 * * * \\
(0.0647)\end{array}$ & $\begin{array}{c}-0.216 * * * \\
(0.0524)\end{array}$ \\
\hline State Fixed Effects & No & Yes & No & Yes \\
\hline County Fixed Effects & No & No & Yes & No \\
\hline Year Fixed Effects & Yes & Yes & Yes & Yes \\
\hline Constant & $\begin{array}{l}-3.177 * * * \\
(1.152)\end{array}$ & $\begin{array}{c}-2.201 * * * \\
(0.851)\end{array}$ & & $\begin{array}{l}-3.716 \\
(2.326)\end{array}$ \\
\hline $\begin{array}{l}\text { Observations } \\
\text { Number of Counties }\end{array}$ & $\begin{array}{c}22,845 \\
2,307\end{array}$ & 23,297 & 10,491 & 23,297 \\
\hline
\end{tabular}

Standard errors in parentheses

$* * * \mathrm{p}<0.01, * * \mathrm{p}<0.05, * \mathrm{p}<0.1$

The pooled ZINB model in Column 2, Table 3 included state-level fixed effects.

Although the regulation variables resulted in a similar pattern to the NB regression in Column 1, 
the number of state regulations in the contemporaneous year is negative but statistically insignificant. However, the one-year lag remains negative and significant. The total population, percentage of the non-white population, percentage of the employed population, and the interaction term variables all closely reflect the results from the panel NB model in model (1).

The results from both the NB and ZINB regression models demonstrate that counties with very large populations experience more violations. This is consistent with the literature on both wastewater and drinking water quality (Earnhart, 2004 and Allaire et al., 2018). Balazs et al. (2011) and Switzer and Teodoro (2018), who all demonstrated that areas with higher non-white populations experience higher numbers of water violations. Our results confirm Switzer and Teodoro (2018) findings and show that increased average per capita income mitigates the number of violations when interacted with the non-white population percentage. Additionally, Earnhart (2004) results showed that having a larger employed population negatively impacts the number of violations in a community.

\subsection{Additional Results}

Additional regression models using wastewater violations and drinking water violations as separate dependent variables with both year and state-level fixed effects are also examined. These models include a negative binomial model, a zero-inflated negative binomial model, a conditional logit model, and a logit model with state fixed effects, similar to the main regression models in Table 3. 
Table 4. Annual County-Level Wastewater Regressions

\begin{tabular}{|c|c|c|c|c|}
\hline Wastewater Violations & $\begin{array}{c}(1) \\
\text { Negative } \\
\text { Binomial, FE } \\
\end{array}$ & $\begin{array}{c}(2) \\
\text { Zero-Inflated } \\
\text { Negative Binomial }\end{array}$ & $\begin{array}{c}\text { (3) } \\
\text { Conditional } \\
\text { Logit } \\
\end{array}$ & $\begin{array}{c}\text { (4) } \\
\text { Logit }\end{array}$ \\
\hline Population, log & $\begin{array}{c}0.178 * * * \\
(0.0162)\end{array}$ & $\begin{array}{c}0.456 * * * \\
(0.0114)\end{array}$ & $\begin{array}{c}0.642 \\
(1.123)\end{array}$ & $\begin{array}{c}0.588 * * * \\
(0.0258)\end{array}$ \\
\hline Non-white percent of pop. & $\begin{array}{l}12.63 * * * \\
(3.522)\end{array}$ & $\begin{array}{l}16.81 * * * \\
(2.477)\end{array}$ & $\begin{array}{l}-61.78 * \\
(36.83)\end{array}$ & $\begin{array}{l}30.43 * * * \\
(6.604)\end{array}$ \\
\hline Employed percent of pop. & $\begin{array}{l}-0.614 * * * \\
(0.142)\end{array}$ & $\begin{array}{r}0.232 * * \\
(0.112)\end{array}$ & $\begin{array}{l}-1.517 \\
(1.159)\end{array}$ & $\begin{array}{l}-0.295 \\
(0.251)\end{array}$ \\
\hline $\begin{array}{l}\text { High school educated } \\
\text { percent of pop. }\end{array}$ & $\begin{array}{c}-1.386^{* * *} \\
(0.354)\end{array}$ & $\begin{array}{l}-1.672 * * * \\
(0.249)\end{array}$ & $\begin{array}{c}5.887 \\
(3.708)\end{array}$ & $\begin{array}{c}-3.025 * * * \\
(0.661)\end{array}$ \\
\hline Per capita income avg. & $\begin{array}{c}0.451 \\
(0.361)\end{array}$ & $\begin{array}{l}-0.325 \\
(0.307)\end{array}$ & $\begin{array}{l}-2.513 \\
(2.989)\end{array}$ & $\begin{array}{l}1.693 * * \\
(0.677)\end{array}$ \\
\hline $\begin{array}{l}\text { Interaction of Non-white \% } \\
\text { and Per capita income }\end{array}$ & $\begin{array}{c}1.164 * * * \\
(0.325)\end{array}$ & $\begin{array}{c}0.298 \\
(0.242)\end{array}$ & $\begin{array}{l}-1.644 \\
(3.133)\end{array}$ & $\begin{array}{l}2.849 * * * \\
(0.520)\end{array}$ \\
\hline Number of state regulations & $\begin{array}{c}0.0275^{* *} \\
(0.0110)\end{array}$ & $\begin{array}{l}0.00271 \\
(0.0179)\end{array}$ & $\begin{array}{l}0.276 * * * \\
(0.0612)\end{array}$ & $\begin{array}{l}0.167 * * * \\
(0.0472)\end{array}$ \\
\hline Regulations lagged 1 yr & $\begin{array}{c}-0.0391 * * * \\
(0.0110)\end{array}$ & $\begin{array}{c}-0.0631 * * * \\
(0.0194)\end{array}$ & $\begin{array}{c}-0.236 * * * \\
(0.0680)\end{array}$ & $\begin{array}{c}-0.138 * * * \\
(0.0504)\end{array}$ \\
\hline State Fixed Effects & No & Yes & No & Yes \\
\hline County Fixed Effects & No & No & Yes & No \\
\hline Year Fixed Effects & Yes & Yes & Yes & Yes \\
\hline Constant & $\begin{array}{c}4.564 * * * \\
(1.242)\end{array}$ & $\begin{array}{c}-3.322 * * * \\
(0.958)\end{array}$ & & $\begin{array}{l}-1.924 \\
(2.211)\end{array}$ \\
\hline $\begin{array}{l}\text { Observations } \\
\text { Number of Counties }\end{array}$ & $\begin{array}{c}21,112 \\
2,179\end{array}$ & 21,973 & 10,196 & 21,973 \\
\hline
\end{tabular}

The SDWA regulates mainly drinking water facilities but also includes standards for sources such as rivers, springs, reservoirs, lakes, and groundwater wells (Tiemann, 2017). This leads to overlapping regulatory standards as the CWA also regulates most of those bodies of water. The quality of the source water before treatment will affect the final drinking water quality. Although drinking water quality is directly enforced by policies implemented under the 
SDWA, we take into account the indirect effect of the CWA policies because of the overlapping oversight of water bodies, which is reflected in the regression results in Table 5.

The results of Table 5 demonstrate that drinking water violations are indeed affected by state-level regulations pertaining to the CWA in the year that a regulation is implemented. These results correspond to the fact that drinking water in the United States is directly regulated by the SDWA, while water quality as a whole is regulated by the CWA. This conclusion is demonstrated by the statistically significant and positive coefficients of the number of state regulations across all four models presented in Table 5. However, there is limited evidence that state-level CWA regulations decrease drinking water violations after the implementation year, as demonstrated by the lag variable. 
Table 5. Annual County-Level Drinking Water Regressions

\begin{tabular}{|c|c|c|c|c|}
\hline Drinking Water Violations & $\begin{array}{c}\text { (1) } \\
\text { Negative } \\
\text { Binomial, FE } \\
\end{array}$ & $\begin{array}{c}(2) \\
\text { Zero-Inflated } \\
\text { Negative Binomial }\end{array}$ & $\begin{array}{c}(3) \\
\text { Conditional } \\
\text { Logit } \\
\end{array}$ & $\begin{array}{l}(4) \\
\text { Logit }\end{array}$ \\
\hline Population, log & $\begin{array}{c}0.209 * * * \\
(0.0271)\end{array}$ & $\begin{array}{c}0.293 * * * \\
(0.0193)\end{array}$ & $\begin{array}{l}-0.628 \\
(0.793)\end{array}$ & $\begin{array}{c}0.430 * * * \\
(0.0194)\end{array}$ \\
\hline Non-white percent of pop. & $\begin{array}{c}6.294 \\
(7.133)\end{array}$ & $\begin{array}{c}24.07 * * * \\
(4.997)\end{array}$ & $\begin{array}{l}-4.206 \\
(29.82)\end{array}$ & $\begin{array}{c}22.55 * * * \\
(4.425)\end{array}$ \\
\hline Employed percent of pop. & $\begin{array}{c}0.372 \\
(0.245)\end{array}$ & $\begin{array}{c}0.587 * * * \\
(0.184)\end{array}$ & $\begin{array}{c}0.767 \\
(0.891)\end{array}$ & $\begin{array}{l}-0.115 \\
(0.187)\end{array}$ \\
\hline $\begin{array}{l}\text { High school educated } \\
\text { percent of pop. }\end{array}$ & $\begin{array}{l}-0.627 \\
(0.715)\end{array}$ & $\begin{array}{l}-2.467 * * * \\
(0.491)\end{array}$ & $\begin{array}{c}0.210 \\
(2.957)\end{array}$ & $\begin{array}{l}-2.315 * * * \\
(0.444)\end{array}$ \\
\hline Per capita income avg. & $\begin{array}{l}-0.950 \\
(0.620)\end{array}$ & $\begin{array}{l}-3.951 * * * \\
(0.565)\end{array}$ & $\begin{array}{c}1.115 \\
(2.171)\end{array}$ & $\begin{array}{l}-1.901 * * * \\
(0.520)\end{array}$ \\
\hline $\begin{array}{l}\text { Interaction of Non-white } \\
\% \text { and Per capita income }\end{array}$ & $\begin{array}{c}-1.851 * * * \\
(0.542)\end{array}$ & $\begin{array}{c}-1.321 * * * \\
(0.441)\end{array}$ & $\begin{array}{c}1.819 \\
(2.471)\end{array}$ & $\begin{array}{c}0.867 * * \\
(0.417)\end{array}$ \\
\hline $\begin{array}{l}\text { Number of state } \\
\text { regulations }\end{array}$ & $\begin{array}{l}0.0899 * * * \\
(0.0193)\end{array}$ & $\begin{array}{l}0.110 * * * \\
(0.0311)\end{array}$ & $\begin{array}{l}0.157 * * * \\
(0.0376)\end{array}$ & $\begin{array}{l}0.116 * * * \\
(0.0321)\end{array}$ \\
\hline Regulations lagged $1 \mathrm{yr}$ & $\begin{array}{c}-0.0786 * * * \\
(0.0192)\end{array}$ & $\begin{array}{l}-0.0140 \\
(0.0339)\end{array}$ & $\begin{array}{l}-0.0499 \\
(0.0430)\end{array}$ & $\begin{array}{l}-0.0280 \\
(0.0339)\end{array}$ \\
\hline State Fixed Effects & No & Yes & No & Yes \\
\hline County Fixed Effects & No & No & Yes & No \\
\hline Year Fixed Effects & Yes & Yes & Yes & Yes \\
\hline Constant & $\begin{array}{l}-4.266 * * \\
(2.162)\end{array}$ & $\begin{array}{l}-6.972 * * * \\
(1.593)\end{array}$ & & $\begin{array}{l}-3.922 * * \\
(1.600)\end{array}$ \\
\hline $\begin{array}{l}\text { Observations } \\
\text { Number of Counties }\end{array}$ & $\begin{array}{c}18,872 \\
1,897\end{array}$ & 22,959 & 17,314 & 22,959 \\
\hline
\end{tabular}

\subsection{Robustness Check}

As acknowledged in Section 5, there is no perfect model for over-dispersed panel data.

We, therefore, compared a ZINB model, which treats the data as pooled, with a negative binomial model, which treats the data as a panel. As a robustness check, we also included a conditional logit model (see Column 3 in Table 3) and a fixed-effects logit model (Column 4 in 
Table 3). The coefficients of both logit models demonstrate the probability of a violation occurring in a county or state given that there is one additional state regulation.

The third model, the conditional logit in Column 3, Table 3, also reflects similar results as the main two models. The results are shown for the specification with year fixed effects. The conditional logit model shows that again, the effect of the number of state regulations in the contemporaneous year is positive and significant, the one-year lag is negative and significant. It also reflects similar coefficient results for the total population and the interaction term.

We also included a logit model, with state and year fixed effects, as one additional check on the consistency of our results. The regulation results match the results from the other three models. In addition, the total population, percent of non-white population, and the interaction term have similar results to the NB and ZINB regression models.

We also ran a NB regression at the state-level (Table 6) and NB and logit regressions at the county-level using the 2017 data (Table 7). These tables show similar results regarding state regulations (Table 3), although the 2017 regression results are not significant.

The NB regression in Table 6 examines drinking and wastewater violations aggregated at the state level. There is a year fixed effect included. The resulting coefficients reflect very closely with the county-level NB model in Table 3 . The state regulations coefficient is positive, while the one-year lag is negative and significant. 


\section{Table 6. Annual State-level Regression}

\begin{tabular}{|c|c|}
\hline $\begin{array}{l}\text { Drinking and Wastewater } \\
\text { Violations }\end{array}$ & $\begin{array}{c}\text { (1) } \\
\text { Negative } \\
\text { Binomial, FE }\end{array}$ \\
\hline Population, log & $\begin{array}{l}0.310^{* *} \\
(0.135)\end{array}$ \\
\hline Non-white percent of pop. & $\begin{array}{l}-17.78 \\
(45.63)\end{array}$ \\
\hline Employed percent of pop. & $\begin{array}{c}1.063 \\
(1.114)\end{array}$ \\
\hline $\begin{array}{l}\text { High school educated } \\
\text { percent of pop. }\end{array}$ & $\begin{array}{c}1.941 \\
(4.534)\end{array}$ \\
\hline Per capita income avg. & $\begin{array}{c}-7.601 * * \\
(3.509)\end{array}$ \\
\hline $\begin{array}{l}\text { Interaction of Non-white } \\
\% \text { and Per capita income }\end{array}$ & $\begin{array}{c}11.40 * * * \\
(4.313)\end{array}$ \\
\hline $\begin{array}{l}\text { Number of state } \\
\text { regulations }\end{array}$ & $\begin{array}{c}0.0459 \\
(0.0360)\end{array}$ \\
\hline Regulations lagged $1 \mathrm{yr}$ & $\begin{array}{l}-0.0580^{*} \\
(0.0351)\end{array}$ \\
\hline Year Fixed Effects & Yes \\
\hline Constant & $\begin{array}{l}-16.13 \\
(11.02)\end{array}$ \\
\hline Observations & 357 \\
\hline Number of States & 36 \\
\hline
\end{tabular}

Regression models in Table 7 reflect the regulatory results in both Tables 3 and 6 . These models are not panel data, as they use the data from only 2017. However, they both have statelevel fixed effects. The NB regression in Column 1 shows the number of state regulations in the contemporaneous year as positive and significant, while the regulations lagged one year is negative and significant. 
The logit model in Column 2 again shows similar results regarding the regulation impacts. The number of state regulations in the contemporaneous year is positive and significant. The one-year lag is negative and statistically significant.

Table 7. 2017 County-level Regressions

\begin{tabular}{|c|c|c|}
\hline $\begin{array}{l}\text { Drinking and } \\
\text { Wastewater Violations }\end{array}$ & $\begin{array}{c}\text { (1) } \\
\text { Negative } \\
\text { Binomial } \\
\end{array}$ & $\begin{array}{l}(2) \\
\text { Logit }\end{array}$ \\
\hline Population, log & $\begin{array}{l}0.456 * * * \\
(0.0304)\end{array}$ & $\begin{array}{l}0.655^{* * * *} \\
(0.0925)\end{array}$ \\
\hline Non-white pop, log & $\begin{array}{l}14.93 * * \\
(6.803)\end{array}$ & $\begin{array}{c}21.43 \\
(20.48)\end{array}$ \\
\hline Employed pop, log & $\begin{array}{c}0.229 \\
(0.301)\end{array}$ & $\begin{array}{l}0.0593 \\
(0.928)\end{array}$ \\
\hline $\begin{array}{l}\text { Highschool educated } \\
\text { pop, log }\end{array}$ & $\begin{array}{l}-1.530 * * \\
(0.681)\end{array}$ & $\begin{array}{l}-2.148 \\
(2.058)\end{array}$ \\
\hline Per capita income, log & $\begin{array}{c}-1.946 * * \\
(0.838)\end{array}$ & $\begin{array}{c}1.266 \\
(2.432)\end{array}$ \\
\hline $\begin{array}{l}\text { Interaction of Non-white } \\
\% \text { and Per capita income }\end{array}$ & $\begin{array}{l}-0.282 \\
(0.640)\end{array}$ & $\begin{array}{c}1.126 \\
(1.806)\end{array}$ \\
\hline $\begin{array}{l}\text { Number of state } \\
\text { regulations }\end{array}$ & $\begin{array}{l}2.949 * * * \\
(0.485)\end{array}$ & $\begin{array}{c}3.853 * * * \\
(1.066)\end{array}$ \\
\hline Regulations lagged $1 \mathrm{yr}$ & $\begin{array}{c}-3.662 * * * \\
(0.577)\end{array}$ & $\begin{array}{c}-4.804 * * * \\
(1.311)\end{array}$ \\
\hline Constant & $\begin{array}{c}-5.757 * * \\
(2.652)\end{array}$ & $\begin{array}{l}-8.944 \\
(8.266)\end{array}$ \\
\hline Observations & 2,093 & 1,839 \\
\hline
\end{tabular}

\subsection{Policy Implications and Discussion}

These results build on related research described in the literature review. States make various regulatory decisions regarding the CWA based on their unique circumstances (Travis et al., 2004) and have varying degrees of CWA enforcement (Rechtschaffen, 2004; Grooms, 2015). No study has considered the state-level stringency of water quality regulations as a factor 
effecting either drinking or wastewater violations. We contribute to the literature by considering the number of state regulations implemented under the CWA, as a measure of state stringency regarding water quality standards. In addition, we considered the effect of CWA regulations on drinking water quality.

The research findings demonstrate that states who enact regulatory standards in addition to the CWA see a decrease in water quality violations, once water systems and counties have time to adjust and respond to the new regulation. A decrease in violations under stricter regulations implies, but does not prove, that an improvement in water quality has taken place. First and foremost, improved water quality improves the population's health, as poor water quality negatively impacts health (Allaire et al., 2018). Additionally, improved water quality should improve overall quality of life as it affects people's health, well-being, industry, and recreational activities.

Our results imply that states with few additional regulations could consider enacting more stringent water quality standards than the CWA in order to decrease their reported violations if that is a state priority. We know from previous literature that some state government leaders may regard water quality as a lower priority than leaders in other states (van't Veld and Shogren, 2012). Other factors that may improve water quality that are not examined in this thesis include better enforcement at the state-level (Grooms, 2015), more funding for treatment plants (McConnell and Schwarz, 1992), or even the EPA stepping in more often, as argued by Rechtschaffen (2004).

Funding for treatment plants is often provided by the state through a federal loan program. The distribution of this federal money is, in part, determined by the overall performance of treatment plants. Plants that have more violations and states with worse water quality, as measured by violations, should ideally be getting access to greater funds to improve 
their performance. Federal dollars are best allocated to poor performing states with lower stringency, as our results show that higher stringency improves future compliance. The marginal productivity of each dollar spent by the government is greater at the poor-performing states with lower standards than better-performing states with a higher standard (Anica and Elbakidze, 2020). The results here show that the compliance record, in terms of the number of violations, depends on not only the operations of the facility but also on additional state-level regulations. In this respect, the use of compliance records for allocating funds to improve compliance performance, without accounting for state-level heterogeneity in regulatory standards can be misleading.

There are limitations to this study, and further research on this topic is needed to better understand the effect of regulatory stringency on state-level CWA compliance. First, counting EPA approved regulations for each state is a basic way to classify overall water quality priorities of a state. Our count representation disregards the nature and stringency of these additional state water regulations. We also assign the regulation to its earliest published year and assume that the regulation remains effective. More in-depth research would include a stronger classification of all water-related regulations in a state and what the regulation or standard may be affecting, be it a pollutant standard or just a requirement of reporting by a particular date.

Second, as discussed earlier, reporting for both wastewater and drinking water violations may not be consistent across states and facilities. In addition, the GAO has found that approximately $26 \%$ of drinking water violations are not reported (US Government Accountability Office, 2011). Rechtschaffen (2004), Konisky and Teodoro (2016), and Allaire et al. (2018) also acknowledge this underreporting.

Third, Chakraborti and McConnell (2012) pointed out the possibility of endogenous permitting standards. This may affect violation rates and may have some implications for the 
results found here. Since these permitting standards are pollutant specific, this issue can be addressed by examining pollutant specific violations. In this study, we focus on the aggregate number of violations and leave the examination of pollutant specific violations for future studies. Further research should also include enforcement factors as well, building off of research by Grooms (2015).

\section{Conclusion}

The Clean Water Act (CWA) was enacted to prohibit the discharge of any regulated pollutant from a point source into navigable waters in the United States without a permit from the EPA. The permits set restrictions on the type and the quantity of pollutants that the owners of the permits can discharge. States and Native American tribes are charged with primary oversight and enforcement responsibility of both the CWA and the SDWA, with a requirement to maintain regulatory standards at least as stringent as the EPA's. States are also able to implement their own regulatory standards in addition to the CWA, making their overall water quality regulation more stringent than the federal standards. We examine how the occurrence of water quality violations differs in states with additional CWA regulatory standards, compared to states who follow only the federal regulatory standards.

Regression models are utilized to evaluate the effects of additional state regulations on the occurrence of water violations, both wastewater and drinking water violations, together and separately. The two main models examined were a pooled ZINB model and a panel NB model. Conditional logit and logit models were also included as robustness checks, in addition to several other models. The results of these regression analyses demonstrate that while violations increase in the year when new state regulations are implemented, increasing the number of state water quality regulations decreases the number of violations after a state regulation has been in place for at least one year. Meaning, the number of violations decreases after facilities have had time to 
adjust to the newer, more stringent requirements. In addition, drinking water violations are affected by state CWA regulations (see Table 5). This is consistent with the expectation, as drinking water in the United States is regulated directly by the SDWA, while the CWA regulates water quality more broadly. 


\section{References}

American Society of Civil Engineers, (2017). "2017 Infrastructure Report Card." https://www.infrastructurereportcard.org

Anica, Sharaban and Levan Elbakidze. (2020, June 26-July 3). Financial assistance and environmental compliance: Evidence from the Clean Water Act (CWA) and the Clean Water State Revolving Fund (CWSRF) [Paper presentation]. European Association of Environmental and Resource Economists $25^{\text {th }}$ Annual Conference, Virtual.

Allaire, Maura, Haowei Wu, and Upmanu Lall. (2018). National trends in water quality violations. Proceedings of the National Academy of Sciences, 115(9), 2078-2083.

Balazs, Carolina, Rachel Morello-Frosch, Alan Hubbard, and Isha Ray. (2011). Social disparities in nitrate contaminated drinking water in California's San Joaquin Valley. Environmental Health Perspective, 119(9), 1272-1278.

Cameron, A. Colin and Pravin Trivedi. (2013). Regression Analysis of Count Data (2nd edition). Econometric Society Monograph No.53. Cambridge University Press.

Chakraborti, Lopamudra and Kenneth McConnell. (2012). Does ambient water quality affect the stringency of regulations? Plant-level evidence of the Clean Water Act. Land Economics, 88(3), 518-535.

Chamberlain, Gary. (1980). Analysis of covariance with qualitative data. Review of Economic Studies 47, 225-238.

Desmarais, Bruce and Jeffrey Harden. (2013). Testing for zero inflation in count models: Bias correction for the Vuong test. The Stata Journal, 13(4), 810-835.

Dijkstra, Bouwe and Per G. Fredriksson. (2010). Regulatory environmental federalism. Annual Review of Resource Economics, 2, 319-339.

Earnhart, Dietrich. (2004). The effects of community characteristics on polluter compliance levels. Land Economics, 80(3), 408-432.

Elbakidze, Levan and Yanhong Jin. (2015). Are economic development and education improvement associated with participation in transnational terrorism? Risk Analysis, 35(8), 15201535 .

Greene, William. (1994). Accounting for excess zeros and sample selection in Poisson and negative binomial regression models. Working paper EC-94-10, Department of Economics, Stern School of Business, New York University.

Greene, William. (2002). The Bias of the Fixed Effects Estimator in Nonlinear Models. Manuscript, Department of Economics, Stern School of Business, New York University.

Grooms, Katherine. (2015). Enforcing the Clean Water Act: The effect of state-level corruption on compliance. Journal of Environmental Economics and Management, 73, 50-78.

Heilbron David. (1994). Zero-altered and other regression models for count data with added zeros. Biometrical Journal, 36(5), 531-547. 
Helland, Eric. (1998). Environmental protection in the federalist system: The political economy of NPDES inspections. Economic Inquiry, 36(2), 305-319.

Konisky, David and Manuel Teodoro. (2016). When governments regulate governments. American Journal of Political Science, 60(3), 559-574.

Levinson, Arik. (2003). Environmental regulatory competition: A status report and some new evidence. National Tax Journal, 56(1), 91-106.

Long, J. Scott and Jeremy Freese. (2014). Regression Models for Categorical Dependent Variables Using Stata (3rd ed). College Station, TX: Stata Press.

McConnell, Virginia and Gregory Schwarz. (1992). The supply and demand for pollution control: Evidence from wastewater treatment. Journal of Environmental Economics and Management, 23(1), 54-77.

Mullahy, John. (1986). Specification and testing of some modified count data models. Journal of Econometrics, 33(3), 341- 365.

Oates, Wallace E. and Paul R. Portney. (2003). The political economy of environmental policy. In K.G. Maler and J.R. Vincent (Eds), Handbook of Environmental Economics (Vol. 1). (pp. 325-354). Amsterdam: Elsevier.

Pashigian, Peter B. (1985). Environmental regulation: Whose self-interests are being protected? Economic Inquiry, 23(4), 551-584.

Peltzman, Sam. (1976) Toward a more general theory of regulation. Journal of Law and Economics, 19(2), 211-240.

Rahman, Tauhidur, Mini Kohli, Sharon Megdal, Satheesh Aradhyula, and Jackie Moxley. (2010). Determinants of environmental noncompliance by public water systems. Contemporary Economic Policy, 28(2), 264-274.

Rachtschaffen, Clifford. (2004). Enforcing the Clean Water Act in the twenty-first century: Harnessing the power of the public spotlight. Alabama Law Review, 55(3), 775-814.

Rubin, Scott. (2013). Evaluating violations of drinking water regulations. Journal of the American Water Resource Association, 105(3), E137-E147.

Stoner, Amanda. (2017). Regulatory deficiencies in wastewater infrastructure in rural Appalachia. Sustainable Development Law and Policy, 18(2), 30-31.

Switzer, David and Manuel P. Teodoro. (2018). Class, Race, Ethnicity, and Justice in Safe Drinking Water Act Compliance. Social Science Quarterly, 99(2), 524-535.

Tiemann, Mary. (2017). Safe Drinking Water Act (SDWA): A summary of the act and its major requirements. (CRS Report no. RL31243). Congressional Research Service, Washington, D.C.

Travis, Rick, John C. Morris, and Elizabeth D. Morris. (2004). State implementation of federal environmental policy: Explaining leveraging in the Clean Water State Revolving Fund. The Policy Studies Journal, 32(3), 461-480. 
U.S. Environmental Protection Agency. (2017, August 8). History of the Clean Water Act. https://www.epa.gov/laws-regulations/history-clean-water-act.

U.S. Environmental Protection Agency. (2019a, September 11). Clean Water Act (CWA) Compliance Monitoring: Wastewater Management. https:/www.epa.gov/compliance/cleanwater-act-cwa-compliance-monitoring.

U.S. Environmental Protection Agency. (2019b, April 8). Toxic and Priority Pollutants Under the Clean Water Act. https://www.epa.gov/eg/toxic-and-priority-pollutants-under-clean-wateract.

U.S. Environmental Protection Agency. (2019c, December 2). About Loading Tool Data: Data Sources for the Water Pollutant Loading Tool. https://echo.epa.gov/trends/loadingtool/resources/about-the-data.

U.S. Environmental Protection Agency. (2019d, July 9). SDWIS Search. https://www.epa.gov/enviro/sdwis-search.

U.S. Environmental Protection Agency. (2019e, December 10). State-Specific Water Quality Standards Effective under the Clean Water Act (CWA). https://www.epa.gov/wqs-tech/statespecific-water-quality-standards-effective-under-clean-water-act-cwa.

U.S. Environmental Protection Agency. (2020a, February 14). National Primary Drinking Water Regulations. https://www.epa.gov/ground-water-and-drinking-water/national-primary-drinkingwater-regulations.

U.S. Environmental Protection Agency. (2020b, February 27). Background on Drinking Water Standards in the Safe Drinking Water Act (SDWA). https://www.epa.gov/sdwa/backgrounddrinking-water-standards-safe-drinking-water-act-sdwa.

U.S. Government Accountability Office. (2009). Clean Water Act: Longstanding issues impact EPA's and states enforcement efforts. Testimony before the Committee on Transportation and Infrastructure. U.S. House of Representatives. https://www.gao.gov/products/GAO-10-165T.

U.S. Government Accountability Office. (2011). Drinking water: Unreliable state data limit EPA's ability to target enforcement priorities and communicate water systems' performance. Report to Congressional Requesters. https://www.gao.gov/products/GAO-11-381.

van't Veld, K., and Jason Shogren. (2012). Environmental federalism and environmental liability. Journal of Environmental Economics and Management, 63(1), 105-119.

Vuong, Quang. (1989). Likelihood ratio tests for model selection and non-nested hypotheses. Econometrica 57, 307-333.

Wallsten, Scott and Katrina Kosec. (2008). The effects of ownership and benchmark competition: An empirical analysis of U.S. water systems. International Journal of Industrial Organization, 26(1), 186-205. 
Water Environment Federation. (2019). Following the flow: An inside look at wastewater treatment. https://www.wef.org/globalassets/assets-wef/3---resources/for-the-public/publicinformation/following-the-flow-book-an-inside-look-at-wastewater-treatment.pdf

Welsh, Alan, Ross Cunningham, Christine Donnelly, and David Lindenmayer. (1996). Modeling the abundance of rare species: Statistical models for counts with extra zeros. Ecological Modeling, 88(1), 297-308.

Wilson, Paul. (2015). The misuse of the Vuong test for non-nested models to test for zeroinflation. Economics Letters, 127, 51-53.

Yip, Karen and Kelvin Yau. (2005). On modeling claim frequency data in general insurance with extra zeros. Insurance: Mathematics and Economics, 36, 153-163. 


\section{Appendix 1.}

\section{Priority Pollutant List}

Priority Pollutants are a set of chemical pollutants we regulate, and for which we have developed analytical test methods. The current list of 126 Priority Pollutants, shown below, can also be found at 40 CFR Part 423, Appendix A.

These are not the only pollutants regulated in Clean Water Act programs. The list is an important starting point for EPA to consider, for example, in developing national discharge standards (such as Effluent Guidelines) or in national permitting programs (such as NPDES).

1. Acenaphthene

2. Acrolein

3. Acrylonitrile

4. Benzene

5. Benzidine

6. Carbon tetrachloride

7. Chlorobenzene

8. 1,2,4-trichlorobenzene

9. Hexachlorobenzene

10. 1,2-dichloroethane

11. 1,1,1-trichloreothane

12. Hexachloroethane

13. 1,1-dichloroethane

14. 1,1,2-trichloroethane

15. 1,1,2,2-tetrachloroethane

16. Chloroethane

17. (Removed)

18. Bis(2-chloroethyl) ether

19. 2-chloroethyl vinyl ethers

20. 2-chloronaphthalene

21. 2,4,6-trichlorophenol

22. Parachlorometa cresol

23. Chloroform

24. 2-chlorophenol

25. 1,2-dichlorobenzene

26. 1,3-dichlorobenzene

27. 1,4-dichlorobenzene

28. 3,3-dichlorobenzidine

29. 1,1-dichloroethylene

30. 1,2-trans-dichloroethylene

31. 2,4-dichlorophenol

32. 1,2-dichloropropane

33. 1,3-dichloropropylene

34. 2,4-dimethylphenol
35. 2,4-dinitrotoluene

36. 2,6-dinitrotoluene

37. 1,2-diphenylhydrazine

38. Ethylbenzene

39. Fluoranthene

40. 4-chlorophenyl phenyl ether

41. 4-bromophenyl phenyl ether

42. Bis(2-chloroisopropyl) ether

43. Bis(2-chloroethoxy) methane

44. Methylene chloride

45. Methyl chloride

46. Methyl bromide

47. Bromoform

48. Dichlorobromomethane

49. (Removed)

50. (Removed)

51. Chlorodibromomethane

52. Hexachlorobutadiene

53. Hexachlorocyclopentadiene

54. Isophorone

55. Naphthalene

56. Nitrobenzene

57. 2-nitrophenol

58. 4-nitrophenol

59. 2,4-dinitrophenol

60. 4,6-dinitro-o-cresol

61. N-nitrosodimethylamine

62. N-nitrosodiphenylamine

63. N-nitrosodi-n-propylamine

64. Pentachlorophenol

65. Phenol

66. Bis(2-ethylhexyl) phthalate

67. Butyl benzyl phthalate

68. Di-N-Butyl Phthalate 
69. Di-n-octyl phthalate

70. Diethyl Phthalate

71. Dimethyl phthalate

72. Benzo(a) anthracene

73. Benzo(a) pyrene

74. Benzo(b) fluoranthene

75. Benzo(k) fluoranthene

76. Chrysene

77. Acenaphthylene

78. Anthracene

79. Benzo(ghi) perylene

80. Fluorene

81. Phenanthrene

82. Dibenzo(,h) anthracene

83. Indeno (1,2,3-cd) pyrene

84. Pyrene

85. Tetrachloroethylene

86. Toluene

87. Trichloroethylene

88. Vinyl chloride

89. Aldrin

90. Dieldrin

91. Chlordane

92. 4,4-DDT

93. 4,4-DDE

94. 4,4-DDD

95. Alpha-endosulfan

96. Beta-endosulfan

97. Endosulfan sulfate

98. Endrin

99. Endrin aldehyde
100. Heptachlor

101. Heptachlor epoxide

102. Alpha-BHC

103. Beta-BHC

104. Gamma-BHC

105. Delta-BHC

106. PCB-1242 (Arochlor 1242)

107. PCB-1254 (Arochlor 1254)

108. PCB-1221 (Arochlor 1221)

109. PCB-1232 (Arochlor 1232)

110. PCB-1248 (Arochlor 1248)

111. PCB-1260 (Arochlor 1260)

112. PCB-1016 (Arochlor 1016)

113. Toxaphene

114. Antimony

115. Arsenic

116. Asbestos

117. Beryllium

118. Cadmium

119. Chromium

120. Copper

121. Cyanide, Total

122. Lead

123. Mercury

124. Nickel

125. Selenium

126. Silver

127. Thallium

128. Zinc

129. 2,3,7,8-TCDD 